\title{
Pengaruh Konseling terhadap Peningkatan Pengetahuan Wanita Pekerja Seks mengenai Infeksi Menular Seksual di Wilayah Cadas Pangeran Kabupaten Sumedang
}

\author{
Upus Piatun Khodijah, ${ }^{1}$ Eka Kartika ${ }^{2}$ \\ ${ }^{1,2}$ Akademi Kebidanan Respati Sumedang
}

\begin{abstract}
Abstrak
Infeksi Menular Seksual (IMS) sampai saat ini masih merupakan masalah kesehatan di seluruh dunia. Insiden maupun prevalensi yang sebenarnya di berbagai negara tidak diketahui secara pasti. Salah satu cara untuk mencegah penyebaran IMS dengan meningkatkan pengetahuan seseorang tentang IMS dengan memberikan informasi atau konseling. Tujuan penelitian untuk mengetahui pengaruh konseling terhadap peningkatan pengetahuan wanita pekerja seks mengenai infeksi menular seksual di Wilayah Cadas Pangeran Kabupaten Sumedang. Jenis penelitian kuantitatif dengan rancangan penelitian quasy experiment. Populasi penelitian seluruh Wanita Pekerja Seksual (WPS) di Cadas Pangeran dan sampel sebanyak 30 orang. Analisis yang digunakan adalah analisis dengan uji t dependen. Hasil penelitian menyatakan sebagian besar responden di Cadas Pangeran Kabupaten Sumedang tahun 2012 memiliki pengetahuan sebelum konseling adalah kurang (50\%) dan sebagian besar responden memiliki pengetahuan sesudah konseling adalah baik $(66,7 \%)$. Ada pengaruh konseling terhadap peningkatan pengetahuan wanita pekerja seks mengenai infeksi menular seksual di Cadas Pangeran Kabupaten Sumedang. Disarankan bagi tenaga kesehatan untuk lebih memerhatikan dan meningkatkan pelayanan untuk pencegahan dan pengobatan infeksi menular seksual, mengingat masih terbatasnya pelayanan kesehatan yang khusus menangani masalah infeksi menular seksual di Kabupaten Sumedang. Selain itu, keterbatasan dana pun menjadi masalah para wanita pekerja seks untuk melakukan pengobatan.
\end{abstract}

Kata Kunci : Infeksi menular seksual, konseling, pengetahuan 


\title{
The Effect of Increased Counseling Awareness Regarding Sex Workers Women Sexually Transmitted Infections in Cadas Pangeran Regional District Sumedang
}

\begin{abstract}
Sexually transmitted infections (STI) is still a wroldwilde health problem, both the developed and developing countries. One way to improve one's knowledge of sexually transmitted infections is to provide information or counseling. This study aims to determine the effect of counseling for female sex workers in Cadas Pangeran Regional District Sumedang. This study is quantitative study using a study design quasy Experiment. Populasi in this study were all women sexual workers in Cadas Pangeran. Sampled as many 30 people. The analysis used $\mathrm{T}$ test analysis dependent. The research resulth reveal that most respondents in Cadas Pangeran district Sumedang, posses good knowledge before coundeling $(66,7 \%)$. There is counseling for increasing knowledge of the influence of women sex workers about sexually transmitted infections in Cadas Pangeran Sumedang. Recommended for health workers to pay mor attention and improvenservices for the prevention and treatment of sexually transmitted infections, given the limited health services that specifially address the issue of sexually transmitted infections in the District of Sumedang. In addition, the lack of funding was an issue of women sex workers to teke medication.
\end{abstract}

Keywords: Counseling, knowledge, sexually transmitted infections

\section{Pendahuluan}

IMS sampai saat ini masih merupakan masalah kesehatan di seluruh dunia, baik di negara maju maupun berkembang. Insiden maupun prevalensi yang sebenarnya di berbagai negara tidak diketahui secara pasti. Berdasarkan laporan yang dikumpulkan oleh World Health Organization (WHO), setiap tahun di seluruh negara terdapat sekitar 250 juta penderita baru meliputi gonorea, sifilis, dan herpes genitalis. Jumlah tersebut menurut WHO cenderung meningkat dari waktu ke waktu. ${ }^{1}$

Data Dinas Kesehatan Kota Sumedang tahun 2010 menemukan kasus penderita infeksi menular seksual dari semua golongan umur diantaranya gonorea 19 orang, trikomonalis vaginalis 29 orang, kandidiasis 26 orang, dan HIV/AIDS 4 orang. ${ }^{2}$

Berdasarkan data di atas, infeksi menular seksual merupakan salah satu penyakit yang penyebarannya sangat pesat tiap tahunnya. Salah satu mediatornya adalah wanita pekerja seks. Penelitian menunjukan wanita pekerja seks berisiko tertular IMS karena adanya perilaku seksial yang berisiko. ${ }^{3}$

Hal ini tentunya menjadi permasalahan bagi wanita pekerja seks pada khususnya dan masyarakat pada umumnya karena protitusi ini menimbulkan dan menyebarluaskan penyakit kelamin dan kulit yang berbahaya serta dapat menyebabkan kematian.

Globalisasi memberikan pengaruh yang cukup nyata dalam masyarakat. Selain itu, dengan globalisasi informasi dari segala penjuru dunia dapat diakses dengan cepat dan mudah. Banyak masyarakat tidak mengetahui apa dan bagaimana cara mereka mendapatkan pelajaran dan pengetahuan tentang masalah seks. Terjadinya Infeksi menular seksual banyak berawal dari pengetahuan masyarakat yang kurang terutama di kalangan wanita pekerja seks. ${ }^{4}$

Menurut Centre for Disease Control and Prevention (2007) diperkirakan bahwa setiap tahun sebanyak 7,4 juta kasus infeksi menular seksual terjadi pada wanita dan laki-laki. ${ }^{5}$ Selain itu, survei sex global oleh perusahaan menyatakan hanya $7 \%$ dari rakyat Indonesia yang memiliki pengetahuan tentang infeksi menular seksual. ${ }^{6}$ Hasil penelitian didapati pengetahuan WPS tentang IMS masih dinilai cukup (84\%). ${ }^{7}$

Walaupun pendidikan tentang penyakit menular seksual telah diberikan kepada masyarakat, namun banyak yang masih kurang memahaminya sehingga penyakit yang ditularkan melalui hubungan seksual masih 
sering terjadi. Untuk itu, masyarakat dan pekerja seks memerlukan pengetahuan dan kehandalan untuk mengatasi permasalahan penyakit menular. Hal ini menyebabkan dibutuhkannya suatu proses berpikir untuk mendapatkan pengetahuan tersebut sehingga dapat memberi gambaran tentang dampak pekerjaan yang dilakukannya, dimana pekerjaan tersebut sangat rentan terhadap penyakit menular yang cukup berbahaya bagi diri maupun orang lain.

Survei pendahuluan yang dilakukan bulan November 2011 oleh peneliti di daerah Cadas Pangeran pada pemilik warung, yaitu dari 10 pemilik warung yang ditemui 8 diantaranya tidak mengetahui mengenai infeksi menular seksual. Untuk itu, perlu dilakukan suatu penelitian dengan memberikan konseling mengenai infeksi menular seksual kepada wanita pekerja seks sehingga terjadi peningkatan pengetahuan dan perubahan perilaku.

Salah satu cara meningkatkan pengetahuan seseorang adalah memberikan informasi atau konseling. Konseling merupakan pertolongan dalam bentuk wawancara yang menuntut adanya komunikasi, interaksi yang mendalam, dan usaha bersama antara konselor dan klien untuk mencapai tujuan konseling yang dapat berupa pemecahan masalah, pemenuhan kebutuhan, ataupun perubahan tingkah laku atau sikap. ${ }^{8}$ Hasil penelitian pada remaja bahwa konseling Kesehatan Reproduksi Remaja (KRR) berpengaruh terhadap pengetahuan dengan skor 7 point lebih tinggi sedangkan sikap 5 point lebih tinggi pada kelompok eksperimen daripada kelompok pembanding. ${ }^{9}$

Jalan Cadas Pangeran merupakan suatu jalan yang dilewati oleh para pengendara kendaraan menuju Bandung ataupun Cirebon dan terdapat warung-warung yang merupakan tempat peristirahatan bagi para pengendara. Observasi yang dilakukan peneliti di warungwarung tersebut terdapat wanita pekerja seks yang merupakan sasaran peneliti dalam melakukan penelitian yang berjudul "Pengaruh Konseling terhadap Peningkatan Pengetahuan Wanita Pekerja Seks mengenai Infeksi Menular Seksual di Wilayah Cadas Pangeran Kabupaten Sumedang Tahun 2012”.

\section{Metode}

Penelitian ini merupakan penelitian kuantitatif dengan rancangan quasy experiment, yaitu one group pre test-post test design. Penelitian ini mengungkapkan hubungan sebab akibat dengan cara melibatkan satu kelompok subjek sehingga dalam rancangan penelitian ini hanya melibatkan kelompok perlakuan tanpa ada kelompok kontrol.

\section{Bagan 1 Rancangan Penelitian}

\begin{tabular}{|l}
\hline $\mathrm{O}$ \\
$\mathrm{K}$
\end{tabular}

Populasi dalam penelitian ini adalah seluruh wanita pekerja seks di Cadas Pangeran dengan teknik sampel non probability sampling, yaitu teknik purposive sampling dengan jumlah sampel minimal sebesar 30 orang dengan kriteria sampel, yaitu wanita pekerja seks yang dapat ditemui oleh peneliti di Cadas Pangeran.

Alat yang digunakan adalah kuisioner yang berisi pertanyaan tentang Infeksi Menular Seksual. Di samping itu, untuk alat bantu konseling menggunakan Satuan Acara Penyuluhan (SAP) dan power point dalam laptop.

Jenis data yang diambil adalah data primer dengan proses pengumpulan data sebagai berikut:

1. Mengadakan pendekatan dan memberikan penjelasan kepada calon responden.

2. Sebelum konseling diberikan, wanita pekerja seksual diminta untuk mengisi kuesioner, kemudian diberikan konseling dengan metode ceramah perorangan dengan power point di laptop tentang infeksi menular seksual, kemudian responden diminta untuk mengisi kuesioner kembali.

3. Membandingkan nilai kuesioner antara sebelum dan sesudah konseling. 
Hasil perubahan pengetahuan wanita pekerja seksual pada penelitian ini dapat dilihat dari nilai kuesioner, dengan ketentuan:

1. Nilai 0 untuk jwaban yang salah.

2. Nilai 1 untuk jawaban yang benar.

Angka hasil perhitungan atau pengukuran, dapat ditentukan menggunakan rumus, sebagai berikut :

$$
\mathrm{P}=\underline{\mathrm{Q}} \times 100 \%
$$

Keterangan :

P : Skor (\%)

$\mathrm{Q}$ : Skor yang diperoleh

$\mathrm{R}$ : Skor maksimal

Nilai pencapaian $\mathrm{P}$ dapat diklasifikasikan menjadi kategori baik (75-100\%), cukup (56$75 \%)$, dan kurang $(<56 \%)$.

Hasil eksperimen pre-test dan post-test terhadap ada dan tidaknya pengaruh konseling terhadap peningkatan pengetahuan PWS tentang IMS dilakukan dengan uji t dependen dengan langkah sebagai berikut:

1. Menentukan hipotesis

2. Hitung t tabel

3. Keputusan dan kesimpulan, $\mathrm{H}_{0}$ gagal ditolak bila harga jumlah jenjang yang terkecil t (dari perhitungan) lebih besar dari harga t tabel:

a. Jika $\mathrm{t}$ hitung $>\mathrm{t}$ tabel, maka $\mathrm{H}_{0}$ gagal ditolak.

b. Jika t hitung $₫$ tabel, maka $\mathrm{H}_{0}$ ditolak

\section{Hasil Penelitian}

WPS dalam penelitian ini didapat 30 orang. Karakteristiknya sebagai berikut:

Tabel 1 Karakteristik Wanita Pekerja Seks

di Cadas Pangeran Tahun 2012

Berdasarkan Umur dan Pendidikan

\begin{tabular}{lcc}
\hline \multicolumn{1}{c}{ Karakteristik } & n & \% \\
\hline Umur & & \\
$<20$ tahun & 2 & $6,6 \%$ \\
20-40 tahun & 24 & $80 \%$ \\
$>40$ tahun & 4 & $13,4 \%$ \\
Pendidikan & & \\
SD & 13 & $43,4 \%$ \\
SMP & 15 & $50 \%$ \\
SMA & 2 & $6,6 \%$ \\
\hline Jumlah & $\mathbf{3 0}$ & $\mathbf{1 0 0 \%}$ \\
\hline
\end{tabular}

Berdasarkan tabel 1, sebagian besar responden berumur antara 20-40 tahun, yaitu sebesar $80 \%$ dan sebagian kecil responden berumur <20 tahun, yaitu sebesar 6,6\%. Penelitian lain menunjukkan insiden tertinggi yang rentan terinfeksi gonore (IMS) pada usia 15-36 tahun, dimana pada usia ini wanita sudah aktif melakukan hubungan seksual. Semakin muda usia wanita maka semakin rentan tertular gonore (IMS). ${ }^{10}$

Berdasarkan pendidikan, sebagian besar responden berpendidikan SMP, yaitu sebesar $50 \%$ dan sebagian kecil responden berpendidikan SMA, yaitu sebesar $6,6 \%$. Diduga pengetahuan berhubungan dengan pendidikan. Semakin tinggi pendidikan maka semakin mengerti seseorang bahwa ia melakukan pekerjaan yang berisiko tinggi terinfeksi gonore (IMS). ${ }^{10}$

Pengetahuan pra konseling menggambarkan pengetahuan wanita pekerja seks sebelum dilakukan konseling tentang infeksi menular seksual. Berdasarkan tabel 2 diketahui sebagian besar responden mempunyai pengetahuan yang kurang, yaitu $50 \%$ dan sebagian kecil responden mempunyai pengetahuan yang cukup, yaitu 20 $\%$.

Tabel 2 Distribusi Frekuensi Pengetahuan Pra Konseling Wanita Pekerja Seks mengenai Infeksi Menular Seksual di Cadas Pangeran Tahun 2012

\begin{tabular}{lcc}
\hline $\begin{array}{c}\text { Pengetahuan Pra } \\
\text { Konseling }\end{array}$ & n & \% \\
\hline Baik & 9 & $30 \%$ \\
Cukup & 6 & $20 \%$ \\
Kurang & 15 & $50 \%$ \\
\hline Jumlah & 30 & $100 \%$ \\
\hline
\end{tabular}

Pengetahuan pasca konseling merupakan pengetahuan wanita pekerja seks setelah dilakukan konseling tentang infeksi menular seksual. Gambaran pengetahuan wanita pekerja seks setelah dilakukan konseling disajikan pada tabel 3 . 
Tabel 3 Distribusi Frekuensi Pengetahuan Pasca Konseling Wanita Pekerja Seks mengenai Infeksi Menular Seksual di Cadas Pangeran Tahun 2012

\begin{tabular}{lcc}
\hline $\begin{array}{c}\text { Pengetahuan } \\
\text { Pasca Konseling }\end{array}$ & n & \% \\
\hline Baik & 20 & $66,7 \%$ \\
Cukup & 10 & $33,3 \%$ \\
Kurang & 0 & $0 \%$ \\
\hline Jumlah & 30 & $100,0 \%$ \\
\hline
\end{tabular}

Berdasarkan tabel 3 dapat diketahui bahwa sebagian besar responden memiliki pengetahuan baik, yaitu $66,7 \%$ dan sebagian kecil responden memiliki pengetahuan yang kurang, yaitu $0 \%$.

Untuk menguji hipotesis yaitu ada pengaruh konseling terhadap peningkatan pengetahuan wanita pekerja seks mengenai infeksi menular seksual, digunakan uji t dependen jika $t_{\text {hitung }}>t_{\text {tabel }}$. Hasil uji statistik pengaruh konseling terhadap peningkatan pengetahuan wanita pekerja seks tersebut dapat dilihat pada tabel 4.

Tabel 4 Hasil Uji Statistik Pengaruh Konseling terhadap Peningkatan Pengetahuan Wanita Pekerja Seks mengenai Infeksi Menular Seksual di Cadas Pangeran Tahun 2012

\begin{tabular}{lccccc}
\hline \multicolumn{1}{c}{ Variable } & Mean & $\begin{array}{c}\text { Standar } \\
\text { deviasi }\end{array}$ & $\begin{array}{c}\text { Standar } \\
\text { error }\end{array}$ & Nilai p & n \\
\hline Pengetahuan pra konseling & 15,3 & 5,72 & 1,04 & 0,000 & 30 \\
Pengetahuan pasca konseling & 24,33 & 3,66 & 0,66 & & \\
\hline
\end{tabular}

Rata-rata pengetahuan sebelum dilakukan konseling adalah 15,33 dengan standar deviasi 5,72 . Pada pengetahuan sesudah didapat 24,33 dengan standar deviasi 3,66. Terlihat nilai mean perbedaan antara pengetahuan sebelum dan sesudah adalah 9,00 dengan standar deviasi 5,318.

Hasil uji statistik didapat nilai p 0,000 (lebih kecil dari $\alpha 5 \%$ ) sehinga $\mathrm{H}_{0}$ ditolak maka dapat disimpulkan ada perbedaan ratarata pengetahuan responden pada pengukuran pertama (sebelum dilakukan konseling) dan pengukuran kedua (sesudah diberikan konseling) atau dengan kata lain ada pengaruh konseling terhadap peningkatan wanita pekerja seks mengenai infeksi menular seksual di Cadas pangeran tahun 2012.

\section{Pembahasan}

Hasil penelitian sebelum peneliti melakukan pendidikan kesehatan mengenai infeksi menular seksual dapat disimpulkan pengetahuan responden kurang, yaitu 50\%. Hal ini disebabkan kurangnya informasi tentang infeksi menular seksual karena keberadaan reponden di lokasi penelitian yang tidak tetap dan cenderung berpindah-pindah sehingga menyulitkan tenaga kesehatan untuk menjangkau para reponden dan memberikan pendidikan kesehatan mengenai infeksi menular seksual.

Setelah diberi konseling pengetahuan, sebagian besar pengetahuan responden adalah baik $(66,7 \%)$. Hal ini menunjukan melalui kegiatan konseling dengan memberikan informasi tentang kesehatan tertentu ternyata dapat memberikan peningkatan pengetahuan.

Hasil penelitian ini sesuai dengan teori yang menyatakan bahwa konseling bisa memberikan informasi tentang masalah masyarakat atau klien yang sedang dihadapi dan sering terkait dengan kurangnya pengetahuan. Masyarakat atau klien juga bisa mendapatkan gambaran (pemahaman) yang jelas terkait dengan isu kesehatan reproduksi dan seksual. Konseling juga digunakan untuk membantu dan memahami lebih lanjut mengenai kesehatan reproduksi dan seksual (memahami diri dan lingkungan). ${ }^{11}$

Hasil penelitian ini sejalan dengan penelitian lain, terdapat hubungan bermakna antara penyuluhan dengan tingkat pengetahuan dan sikap mengenai HIV, serta tingkat pengetahuan, sikap, dan perilaku mengenai VCT, dan tidak terdapat hubungan bermakna dengan perilaku mengenai HIV. ${ }^{12}$ 
studi lain juga menunjukkan konseling behavioral teknik latihan asertif dan penguatan positif berpengaruh terhadap peningkatan academic self-efficacy. ${ }^{13}$

Hasil penelitian tetang pemahaman WPS mengenai bahaya HIV/AIDS menyebabkan adanya suatu upaya pencegahan penularan dan mendeteksi dini status HIV dengan mendatangi klinik VCT, namun ada WPS yang tidak mau mengaksesnya karena takut dengan konsekuensi yang harus diterima ketika dinyatakan positif terinfeksi HIV. WPS merasa takut jika dilarang bekerja dan dijauhi pelanggan, serta takut akan stigma dan diskriminasi dari masyarakat. ${ }^{14}$

Aktivitas konseling terdiri dari pemberian informasi mengenai kesehatan seksual dan reproduksi supaya memiliki usaha untuk melakukan aktivitas-aktivitas yang bersifat positif, pencegahan dengan mengadakan program-program penyuluhan kesehatan dan pencegahan masalah atau penyakit menular seksual, intervensi yaitu mengubah dan membuka pikiran, perasaan dan tingkah laku responden supaya memperluas, memulih dan meningkatkan pengetahuan kesehatan dan pemulihan yaitu penekanan kepada isu-isu dan permasalahan kesehatan reproduksi dan seksual dan mentalitas.

Konseling merupakan suatu proses yang sistematik berdasarkan prinsip psikologi yang dilakukan oleh konselor profesional untuk menghasilkan perubahan, perkembangan dan penyesuaian pribadi klien, yang baik dan menyeluruh secara sukarela sepanjang hayat berlandaskan etika konseling

Steadman's Medical

mendefinisikan konseling sebagai suatu hubungan profesional dan aktivitas dimana satu pihak berusaha membantu pihak yang lain untuk memahami dan menyelesaikan masalah adaptasinya, pemberian nasihat, pendapat dan instruksi untuk memberikan keputusan. Pada umumnya responden akan bertambahan pengetahuannya setelah langsung diberikan konseling oleh konselor professional $^{11}$

Pada penelitian ini peneliti bermaksud untuk membantu meringankan masalah infeksi menular seksual yang marak terjadi di kalangan para wanita pekerja seks dengan memberikan intervensi berupa pendidikan kesehatan, yaitu konseling tentang infeksi menular seksual, setelah dilakukan pre-test hasil menunjukan pengetahuan responden kurang, maka peneliti memberikan konseling dari individu ke individu. Hasil penelitian menunjukan setelah dilakukan intervensi, pengetahuan wanita pekerja seks ini meningkat baik hingga mencapai angka $66,7 \%$. Hal ini dipengaruhi oleh faktor umur, dimana hampir $80 \%$ responden masuk dalam rentang umur 20-40 tahun. Usia ini termasuk dalam kategori dewasa menengah, dimana pada usia ini memungkinkan penerimaan informasi secara baik dan fungsi pengingat yang berjalan dengan baik pula. Selain itu, responden yang berpengetahuan baik ini dapat juga dipengaruhi oleh pendidikan. Dari seluruh responden ini tidak ada yang tidak pernah bersekolah, hampir $50 \%$ responden berpendidikan sampai SMP. Berdasarkan penelitian menunjukan bahwa partisipasi pelanggan WPS di resosialisasi Argorejo dalam melakukan VCT masih rendah 60,2 $\% .^{15}$

\section{Simpulan}

Berdasarkan hasil penelitian ini terbukti ada pengaruh konseling terhadap pengetahuan maka perlu adanya peningkatan kegiatan konseling baik oleh petugas kesehatan maupun lembaga sosial yang ada di wilayah Sumedang sehingga pengetahuan wanita pekerja seks tentang infeksi menular seksual bertambah luas. Di samping itu, agar setiap wanita pekerja seks lebih termotivasi dalam mencari informasi dari berbagai media baik dari internet, TV, maupun surat kabar sehingga diharapkan terjadi perubahan tingkah laku para wanita pekerja seks menjadi lebih baik.

\section{Daftar Pustaka}

1. Widyawati. Trichomonas Vaginalis-Protozoa Patogen Saluran Urogenital. USU Repository, 2006. Available from: http://library.usu.ac.id/download/fk/06001195. pdf

2. Profil Kesehatan. Kabupaten Sumedang. Dinkes 2010.

3. Arifianti, Nur Azm. Analisis Faktor-faktor Penyebab Niat Wanita Pekerja Seks (WPS) yang menderita IMS Berperilaku Seks Aman (Safe Sex) Dalam Melayani Peanggan. Diakses 
dari http://ejournal.undip.ac.id pada tanggal 10 November 2015

4. Daili, dkk. Infeksi menular seksual. Jakarta: Balai penerbit FKUI. 2005.

5. Centers for Disease Control and Prevention. Sexually Transmitted Disease Surveillance 2007 - Division of STD Prevention December 2008. 2007

6. Department of Health and Human Services, Centers for Disease Control and Prevention. USA:Availablefrom:http://www.cdc.gov/std/st ats07/Surv200 FINAL.pdf

7. Darmawan, Dadang. Pengaaruh Pendidikan Kesehatan Terhadap Pengetahuan Pekerja Seks Komersial Tentang Penyakit Menular Seksual di Desa Padalarang Kabupaten Bandung Barat. Diakses dari http://stikesayani.ac.id pada tanggal 11 November 2015

7. Durex. Give and Receive 2005 Global Sex Survey. Durex. USA: 2006. Available from: www.durex.com/en-

jp/sexualwellbeingsurvey/.../gss2005result.pdf

8. Khunti, Dyan. Pengaruh Konseling Kesehatan Reproduksi Remaja Terhadap Pengetahuan dan Sikap Seksual Remaja Studi di SMAN Margahayu Bandung. Diakses dari http://stikesayani.ac.id pada tanggal 10 November 2015

9. Kartika, Putri. Kejadian Infeksi Gonore Pada Pekerja Seks Komersial di eks lokalisasi Pembatuan Kecamatan Landasan Ulin
Banjarbaru. Diakses dari http://ejournal.litbang.depkes.go.id pada tanggal 11 November 2015

10. Kurniawati, N. D. Asuhan Keperawatan pada Pasien yang Terinfeksi HIV/ AIDS. Jakarta: Salemba Medika.2007.

11. Tjan, S. Hubungan Penyuluhan dengan Pengetahuan, Sikap, dan Perilaku Ibu Hamil tentang HIV dan Program Voluntary and Testing (VCT)

12. Wayan, I Midun. Efektifitas Model Konseling Behavioral Teknik Latihan Asetif dan Teknik Penguatan Positif dalam Meningkatkan Academic Self-Efficacy Pada Siswa Kelas VII SMP Negeri 2 Singaraja Tahun Pelajaran 2013/2014

13. Basri, Hasan. Persepsi Wanita Pekerja Seks (WPS) terhadap Uji dan Konseling HIV di Daerah Istimewa Yogyakarta. Universitas Gajah Mada. Yogyakarta:2009 Diakses dari http://etd.repository.ugm.ac.id/index.php?mod =penelitian_detail\&sub=PenelitianDetail\&act= view\&typ=html\&buku_id=42491 pada tanggal 12 November 2015

14. Ika, Arulita. Keikutsertaan Pelanggan Wanita Pekerja Seks Dalam Voluntary Conseling and Testing (VCT) diunduh dari http://journal.unnes.ac.id/nju/index.php/kemas/ article/view/2640 pada tanggal 12 November 2015 